\title{
Neonatal Sepsis by Bacteria: A Big Problem for Children
}

\section{Emma Saez-Lopez, Elisabet Guiral and Sara M Soto*}

Barcelona Centre for International Health Research (CRESIB, Hospital Clinic-University of Barcelona), Barcelona, Spain

\section{Introduction}

Neonatal sepsis is an important but underestimated problem around the world. It is defined as disease affecting newborns $\leq 1$ month of age with clinical symptoms and positive blood cultures. Infection is an important cause of morbidity and mortality during the neonatal period, despite the great improvements in intensive neonatal care and the use of extended spectrum antimicrobial agents. The incidence of this disease in developed countries is $1 / 1,000$ in normal term neonates and 4/1,000 in preterm neonates. These values increase in low-weight preterm neonates [1]. In developing countries, this incidence increases to 2.2-8.6/1,000 live births [2]. Neonatal sepsis can be subdivided into early-onset neonatal sepsis and late-onset neonatal sepsis.

\section{Early Onset Neonatal Sepsis}

EONS can be acquired vertically from the pregnant woman before or during delivery. In this case, microorganisms present in the genital tract of the mothers are of great importance [3]. The symptoms appear within the 72 hours of life. EONS is a serious problem among verylow-birth-weight (VLBW) neonates and is associated with at least a three-fold increased risk of mortality [4]. The estimated incidence in this group is about 15-19/1000 live births [5].

Among the risk factors associated with EONS, the duration of gestation at delivery and the presence of maternal genital tract infection are the most common. In the case of early neonatal sepsis caused by bacteria, these microorganisms could arise from a prematurely ruptured amniotic membrane which becomes infected generally affecting the amniotic fluid or preterm delivery in a mother colonized by such bacteria and who may have a much higher risk of infecting their offspring due to the immaturity of their immune system [6,7]. The intraamniotic infection can affect maternal tissues such as decidua and myometrium, and also fetal tissues such as amniotic and chorionic membranes (chorioamnionitis), amniotic liquid (amnionitis), umbilical cord (funisitis) and placenta (vilitis) [8]. The microorganisms can arrive to the amniotic cavity through the blood system of the placenta, by invasive procedures during gestation (amniocentesis, etc) and by an ascending pathway [9].

Ascending infection from the genital tract of the mother to the fetus requires the following steps [9]:

\section{I- Presence of bacteria in the vagina/cervix.}

II- Bacteria residing in the decidua.

III- The bacteria might colonize the amnion or the chorion, going through the fetal vessels or crossing the amnion, reaching the amniotic cavity.

IV- The bacteria enter the fetus through contact with the infected amniotic liquid and reach the blood, causing sepsis.

Intrauterine or congenital transmission through the placenta affecting the fetus during pregnancy should be differentiated from perinatal transmission, which takes place at delivery and is caused by contact with the microbiota of the birth canal and perineal area.

The main vertically transmitted microorganisms causing EONS

\begin{tabular}{|l|c|c|c|c|}
\hline Reference & Geographical area & Period & GBS & E.coli \\
\hline $\begin{array}{l}\text { Brzarro et aL (2005) } \\
\text { [12] }\end{array}$ & Yale (USA) & $1989-2003$ & $49 \%$ & $24 \%$ \\
\hline $\begin{array}{l}\text { Coben-Wolanarez et } \\
\text { al. (2009) [13] }\end{array}$ & USA & $1996-2007$ & $1.01 / 1,000$ & $0.65 / 1,000$ \\
\hline $\begin{array}{l}\text { Van den hoggen et } \\
\text { al. (2010)[14] }\end{array}$ & Netherlands & $2003-2006$ & $0.7 \%$ & $0.2 \%$ \\
\hline $\begin{array}{l}\text { Vergnano et al. } \\
\text { (2011)[15] }\end{array}$ & England & $2006-2008$ & $50 \%$ & $18 \%$ \\
\hline $\begin{array}{l}\text { Sgro et al. (2011) } \\
\text { [16] }\end{array}$ & Canada & $2006-2008$ & $163 \%$ & $264 \%$ \\
\hline \begin{tabular}{l} 
Stoll et al. (2011)[17] \\
\hline $\begin{array}{l}\text { Weston et al. (2011) } \\
\text { [18] }\end{array}$
\end{tabular}$\quad$ USA & $2006-2009$ & $43 \%$ & $29 \%$ \\
\hline
\end{tabular}

Table 1: Frequencies of GBS and E. coli described in several studies on EONS

are Streptococcus agalactiae (or group B Streptoccocus GBS) and Escherichia coli, followed by Coagulase-negative Staphylococcus (CONS), Haemophylus influenza and Listeria monocytogenes [3]. These microorganisms are an important source of problems for the health of neonates worldwide.

Several studies have corroborated this etiological data. Stoll et al. [10] found that $44 \%$ and $10.7 \%$ of EONS were caused by E. coli and SGB, respectively. Among EONS cases Vergnano et al. [11] reported that $50 \%$ were caused by SGB and $18 \%$ by $E$. coli, this last microorganism being more frequent among very low birth-weight (VLBW) neonates. Other studies are compiled in Table 1 [12-18].

Dagnew et al. [19] carried out a review of the studies about the frequency of GBS causing EONS in developing countries. The incidence rate of 0-2.06 per 1,000 live births and the prevalence of other microorganisms causing EONS varied within and between geographic regions. In Arabic countries, Gram-negative microorganisms are more frequently found as cause of EONS than Gram-positive microorganisms [20]. Finally, Klebsiella spp. (from blood samples) and Staphylococcus aureus (from pus swabs samples) were the bacteria more frequently involved in EONS in Tanzania [21].

\section{Late Onset Neonatal Sepsis}

LONS occurs at 4-90 days of life and is acquired from the care giving environment [22]. The incidence ranges from 1.87 to $5.42 \mathrm{per}$ 1,000 live births [11]. The microorganisms most frequently found to cause LONS are CONS, Staphylococcus aureus, E. coli, Klebsiella,

*Corresponding author: Sara M. Soto, Barcelona Centre for International Health Research (CRESIB, Hospital Clinic-University of Barcelona), Barcelona Spain, Tel: +34-932275707; E-mail: ssoto@clinic.ub.es; sara.soto@cresib.cat

Received July 26, 2013; Accepted August 14, 2013; Published August 16, 2013

Citation: Saez-Lopez E, Guiral E, Soto SM (2013) Neonatal Sepsis by Bacteria: A Big Problem for Children. Clin Microbial 2: 125. doi: 10.4172/2327-5073.1000125

Copyright: ( 2013 Saez-Lopez E, et al. This is an open-access article distributed under the terms of the Creative Commons Attribution License, which permits unrestricted use, distribution, and reproduction in any medium, provided the original author and source are credited. 


\begin{tabular}{|c|c|c|c|c|c|c|}
\hline Reference & Geographical area & Period & GBS & E.coli & S. aureus & CONS \\
\hline Bizzaro et al. [12] & Yale (USA) & $1989-2003$ & $4 \%$ & $10 \%$ & $7 \%$ & $43 \%$ \\
\hline Cohen-Wolkowiez et al. [15] & USA & $1996-2007$ & $0.24 / 1,000$ & $0.6 / 1,000$ & $1.01 / 1,000$ & $1.22 / 1,000$ \\
\hline Vergnano at al. [14] & England & $2006-2008$ & $8 \%$ & $13 \%$ & $18 \%$ & $54 \%$ \\
\hline Waters et al. (23] & Low \& middle income countries & $1980-2010$ & $2.4 \%$ & $12.2 \%$ & $14.9 \%$ & \\
\hline Hammoud et al. (26] & Kuwait & $2005-2009$ & $0.3 \%$ & $5.8 \%$ & $1.7 \%$ & $35.5 \%$ \\
\hline Didier C et al. [25] & Alasce (France) & 2007 & $7 \%$ & $56 \%$ & $12.7 \%$ & $13.6 \%$ \\
\hline Downie et al. [27] & Developing countries & $1993-2009$ & $6 \%$ & $8 \%$ & $25 \%$ & $2 \%$ \\
\hline
\end{tabular}

Table 2: Studies about etiology of LONS

Pseudomonas, Enterobacter, Candida, GBS, Serratia, Acinetobacter and Anaerobes $[11,20,23]$. The main risk factors associated with LONS are prematurity, central venous catheterization (duration $>10$ days), nasal canula, gastrointestinal tract pathology, exposure to antibiotics, and prolonged hospitalization [7, 24]. Didier et al. [25] found three major types of late onset neonatal infections (LONI): E. coli-induced urinary tract infection, CONS septicemia affecting preterm infants and severe GBS infections. Other studies are compiled in Table 2.

In spite of the decrease of early-onset GBS sepsis due to the implementation of universal screening and intrapartum prophylaxis, late-onset GBS sepsis remains unchanged, being an important public health problem and associated with a high mortality and morbidity in preterm newborns [25]. This observation is in accordance with the hypothesis that LONS is usually acquired from the environment.

Several studies have related antenatal antibiotic treatment to the increase of antibiotic-resistant cases of LONS, mainly due to E. coli [2528].

To prevent nosocomial infections, it is important that good the hand hygiene that has been promoted by several global programs is carried out. Intravascular catheters and the fragile skin of the neonates are important points of entrance for intrahospital microorganisms with the consequent risk of neonatal sepsis [29].

\section{Symptoms and Diagnosis}

The clinical symptoms manifested by neonates with EONS and LONS are non-specific and usually include temperature instability, respiratory problems, apnea, feeding intolerance, etc. [7]. Generally, the diagnosis of neonatal sepsis diagnosis is carried out by blood, CSF and urine cultures. Nowadays, other diagnostic tools such as complete blood cell count, C-reactive protein, procalcitonin, mannose binding lectin, cytokine profile, etc. are being studied. In the case of LONS, acute phase reactants, chemokines and cytokines, and cell-surface antigens are non-specific biomarkers that have been studied for diagnosis and management [30]. More recently, the use of genomics and proteomics are being analyzed for detecting neonatal sepsis.

The diagnosis of well-defined neonatal sepsis is difficult due to the high number of negative cultures. For this reason, the term of clinical sepsis has been created based on the symptoms and clinical characteristics presented by the neonate [31].

\section{Neonatal Sepsis Treatment}

Antimicrobial treatment of neonates with suspected sepsis must start immediately after birth and without delay. The isolation and antimicrobial susceptibility tests are not immediately available and results are not obtained in 24 hours. For these reasons, antimicrobial treatment is usually empirical using antibiotics effective against the most likely pathogens [32]. The empirical treatment of EONS consists of ampicillim $(\mathrm{Am})$ and gentamicin $(\mathrm{Gm})$, which cover common pathogens such as GBS, Gram-negative bacteria and Listeria and have synergic action. The combination of ampicillim - cefotaxime is only given in the case of meningitis determined by CSF positivity or by clinical suspicion. In the case of LONS, the therapy must be of extended spectrum antibiotics in order to cover Gram-negative and Gram-positive microorganisms. The duration of antibiotic therapy is of 10 days in EONS without meningitis, 10-14 days in LONS without meningitis, and 14-22 days in the cases of neonatal meningitis. However, an increase in the percentage of Gram-negative bacteria resistant to Am and $\mathrm{Gm}$ has been observed $[24,33,34]$. Several studies found that the $75-78 \%$ of $E$. coli strains causing EONS were ampicillin-resistant and 19-53\% were gentamicin-resistant [24, 33]. In the case of E. coli isolates from LONS, between $19-50 \%$ were ampicillin-resistant and $9-16 \%$ were gentamicin-resistant $[24,33]$. This trend has also been observed in developing countries [35]. For these reasons, although the current guidelines for empirical therapy in neonates seem to be appropriate [32], it is necessary to carry out studies about the susceptibility of bacteria causing neonatal sepsis in order to avoid an emergence and/ or an increase in resistance levels. After empirical treatment, the choice of the antibiotics depends on the microorganism isolated, their antimicrobial susceptibility and the mechanisms of resistance used by the microorganism.

\section{CDC Prophylaxis Guidelines}

Streptococcus agalactiae or group B Streptococcus (GBS) has been the main etiologic agent of early neonatal sepsis in developed countries. In developing countries, this remains to be confirmed, although the few reports available point out that GBS is also a highly prevalent cause of neonatal infections. This microorganism belongs to the gastrointestinal tract microbiota from where it can colonize the vagina. Colonization of a pregnant woman's vagina is very important, as it implies an enhanced risk of GBS being transmitted vertically to the child before or at birth, and subsequently causing infection in the newborn. In Spain, it has been reported that $10-18.5 \%$ of pregnant women are colonized by GBS [36] ; 22.76\% in Tehran [37] ; 6\% in Iran [38]; 19\% in Poland [39]; and 20\% in Taiwan [40]. To avoid this enhanced risk of vertical transmission, several diagnostic and prophylactic protocols have been proposed. In 1996, the Center of Disease Control (CDC) recommended taking vaginal and rectal samples from pregnant women in their last antenatal visit and administering a prophylactic antibiotic such as penicillin $G$ or ampicillin during pregnancy or at the time of delivery in women found to be colonized by GBS in antenatal screenings. If the pregnant woman is allergic to betalactamics, erythromycin or clindamycin must be used [41]. When implemented, the use of these prophylactic measures resulted in a decrease in the incidence of infection by GBS. A good example of this success was a study carried out in 10 hospitals of Barcelona (Spain) in which it was found that the incidence of GBS as cause of neonatal sepsis was reduced from 1.92/1.000 newborns in 1994 to $0.26 / 1.000$ newborns in 2001 ( $p<0,001$ ) [42]. Another study revealed a decrease in the incidence of GBS vertically transmitted 
Citation: Saez-Lopez E, Guiral E, Soto SM (2013) Neonatal Sepsis by Bacteria: A Big Problem for Children. Clin Microbial 2: 125. doi: 10.4172/23275073.1000125

Page 3 of 4

\begin{tabular}{|l|c|c|c|c|}
\hline \multirow{2}{*}{ Reference } & \multicolumn{2}{|c|}{ Before IAP } & \multicolumn{2}{c|}{ After IAP } \\
\cline { 2 - 5 } & GBS & E. coli & G B S & E. coli \\
\hline Levine etal. [56] & $1.7 / 1,000$ & $0.29 / 1,000$ & 0 & $1.3 / 1,000$ \\
\hline Stoll etal. [10] & $5.9 / 1,000$ & $3.2 / 1,000$ & $1.7 / 1,000$ & $6.8 / 1,000$ \\
\hline Dairyet al. [57] & $1.43 / 1,000$ & $0.3211,000$ & $0.25 / 1,000$ & no change \\
\hline Lopez-Sastre etal. [43] & $1.10 / 1,000$ & $0.17 / 1,000$ & $0.7 / 1,000$ & $0.38 / 1,000$ \\
\hline Schrag etal. [1] & $1.7 / 1,000$ & $3.211,000$ & $0.34 / 1,000$ & $6.8 / 1,000$ \\
\hline van den Hoo chen et al. [14] & $1.8 \%$ & $1 \%$ & $0.7 \%$ & $0.3 \%$ \\
\hline Lin etal. [55] & $45.4 \%$ & $40.9 \%$ & $20 \%$ & $70 \%$ \\
\hline
\end{tabular}

Table 3. Studies on the effect of intrapartum prophylaxis and the percentage of GBS and E. coli.

neonatal sepsis from $65.4 \%$ to $36.4 \%$ due to the CDC prophylaxis [43]. Data reported by the CDC showed that after implementation of the guidelines, the incidence of EONS by GBS reduced from 1.7/1000 live births in 1993 to $0.34 / 1000$ live births in 2004 [44].

With intrapartum prophylaxis, the proportion of women exposed to intrapartum antibiotics has doubled [45]. In addition, the incidence of bacterial species causing EONS has changed. Several studies have associated this change in the etiology of EONS with the implementation of GBS prophylaxis. Thus, EONS by GBS has decreased but an increase in the rates of other microorganisms has been reported, mainly $E$. coli $[1,46,47]$ especially in low-birth weight infants [43].

Nonetheless, not only has a change in the etiology of EONS been observed but an increase in Am-resistant bacteria causing EONS has also been described $[24,33,34]$. In the last years, GBS presenting reduced penicillin susceptibility (PRGBS) has been reported $[48,49]$. The increase in the levels of penicillin resistance has been attributed to amino acid substitutions in the penicillin-binding protein $2 \mathrm{X}$. These isolates also presented fluoroquinolone and/or macrolide resistance [50,51]. In addition, it is estimated that about the $12.45-48 \%$ of GBS isolates from EONS were erythromycin-resistant and about the 11.8$28 \%$ were clindamycin-resistant $[41,52,53]$ being a serious problem for empirical prophylaxis.

Several studies have found a relationship between the increase of the administration of intrapartum prophylaxis and the increase of EONS by non-group B streptococcal microorganisms that are resistant to ampicillin $[10,43,54]$. Friedman et al. [24] found an association between the emergence of resistant $E$. coli and PROM, high temperature and intrapartum prophylaxis. However, other studies did not find a significant change in the incidence of ampicillin-resistant non-group $\mathrm{B}$ streptococcal microorganisms causing EONS after implementation of GBS screening and intrapartum prophylaxis. Lin et al. [37] described an incidence of ampicillin-resistant E. coli of about $88.9 \%$ in 2004 and 92.9\% in 2008. Schrag et al [1] determined that exposure to intrapartum antibiotic therapy did not increase early-onset $E$. coli infection but it was only effective in preventing $E$. coli infection among term neonates (Table 3) [55-57].

\section{Conclusion}

Neonatal sepsis remains an important but underestimated problem around the world. In spite of intrapartum prophylaxis, epidemiological surveillance of other pathogens causing early-onset neonatal sepsis is needed. The development of pathogen-specific strategies to prevent this infection could be an important diagnostic tool to reduce the cases of early-onset neonatal sepsis. In addition, studies on antimicrobial resistance of the microorganisms causing neonatal sepsis are needed in order to improve empirical treatment and avoid the emergence of resistances.

\section{References}

1. Schrag SJ, Stoll BJ (2006) Early-onset neonatal sepsis in the era of widespread intrapartum chemoprophylaxis. Pediatr Infect Dis J 25: 939-940.

2. Vergnano S, Sharland M, Kazembe P, Mwansambo C, Heath PT (2005) Neonatal sepsis: an international perspective. Arch Dis Child Fetal Neonatal Ed 90: F220-224.

3. Sgro M, Shah PS, Campbell D, Tenuta A, Shivananda S, et al. (2011) Earlyonset neonatal sepsis: rate and organism pattern between 2003 and 2008. J Perinatol 31: 794-798.

4. Klinger G, Levy I, Sirota L, Boyko V, Reichman B, et al. (2009) Epidemiology and risk factors for early onset sepsis among very-low-birthweight infants. Am J Obstet Gynecol 201: 38.

5. Stoll BJ, Hansen NI, Higgins RD, Fanaroff AA, et al. (2005). Very low birth weight preterm infants with early onset neonatal sepsis: the predominance of gram-negative infections continues in the National Institute of Child Health and Human Development Neonatal Research Network, 2002-2003. Pediatr Infect Dis J. 24: 635-639.

6. Raymond J, Lopez E, Bonacorsi S, Poyart C, Moriette G, et al. (2008) Evidence for transmission of Escherichia coli from mother to child in late-onset neonatal infection. Pediatr Infect Dis J 27: 186-188.

7. Camacho-Gonzalez A, Spearman PW, Stoll BJ (2013) Neonatal infectious diseases: evaluation of neonatal sepsis. Pediatr Clin North Am 60: 367-389.

8. Henneke P, Berner R (2006) SIRS and group-B streptococcal sepsis in newborns: pathogenesis and perspectives in adjunctive therapy. Semin Fetal Neonatal Med 11: 333-342.

9. Cornette $L$, Miall $L(2006)$ Development of regional guidelines: the way forward for neonatal networks? Arch Dis Child Fetal Neonatal Ed 91: F318-319.

10. Stoll BJ, Hansen N, Fanaroff AA, Wright LL, Carlo WA, et al. (2002) Changes in pathogens causing early-onset sepsis in very-low-birth-weight infants. N Engl J Med 347: 240-247.

11. Vergnano S, Menson E, Kennea N, Embleton N, Russell AB, et al. (2011) Neonatal infections in England: the NeonIN surveillance network. Arch Dis Child Fetal Neonatal Ed 96: F9-9F14.

12. Bizzarro MJ, Raskind C, Baltimore RS, Gallagher PG (2005) Seventy-five years of neonatal sepsis at Yale: 1928-2003. Pediatrics 116: 595-602.

13. Cohen-Wolkowiez M, Moran C, Benjamin DK, Cotten CM, Clark RH, et al (2009) Early and late onset sepsis in late preterm infants. Pediatr Infect Dis J 28: $1052-1056$

14. van den Hoogen A, Gerards LJ, Verboon-Maciolek MA, Fleer A, Krediet TG (2010) Long-term trends in the epidemiology of neonatal sepsis and antibiotic susceptibility of causative agents. Neonatology 97: 22-28

15. Vergnano S, Menson E, Kennea N, Embleton N, Russell AB, et al. (2011) Neonatal infections in England: the NeonIN surveillance network. Arch Dis Child Fetal Neonatal Ed 96: F9-9F14.

16. Sgro M, Shah PS, Campbell D, Tenuta A, Shivananda S, et al. (2011) Earlyonset neonatal sepsis: rate and organism pattern between 2003 and 2008 . J Perinatol 31: 794-798.

17. Stoll BJ, Hansen NI, Sánchez PJ, Faix RG, Poindexter BB, et al. (2011) Early onset neonatal sepsis: the burden of group B Streptococcal and E. coli disease continues. Pediatrics 127: 817-826.

18. Weston EJ, Pondo T, Lewis MM, Martell-Cleary P, Morin C, et al. (2011) The burden of invasive early-onset neonatal sepsis in the United States, 20052008. Pediatr Infect Dis J 30: 937-941.

19. Dagnew AF, Cunnington MC, Dube Q, Edwards MS, French N, et al. (2012) Variation in reported neonatal group $B$ streptococcal disease incidence in developing countries. Clin Infect Dis 55: 91-102.

20. Tosson AM, Speer CP (2011) Microbial pathogens causative of neonatal sepsis in Arabic countries. J Matern Fetal Neonatal Med 24: 990-994.

21. Mhada TV, Fredrick F, Matee MI, Massawe A (2012) Neonatal sepsis a Muhimbili National Hospital, Dar es Salaam, Tanzania; aetiology, antimicrobial sensitivity pattern and clinical outcome. BMC Public Health. 12: 904-910.

22. Bizzarro MJ, Raskind C, Baltimore RS, Gallagher PG (2005) Seventy-five years of neonatal sepsis at Yale: 1928-2003. Pediatrics 116: 595-602. 
Citation: Saez-Lopez E, Guiral E, Soto SM (2013) Neonatal Sepsis by Bacteria: A Big Problem for Children. Clin Microbial 2: 125. doi: 10.4172/23275073.1000125

23. Waters D, Jawad I, Ahmad A, LukÅ iï̈ł I, Nair H, et al. (2011) Aetiology of community-acquired neonatal sepsis in low and middle income countries. J Glob Health 1: 154-170.

24. Friedman S, Shah V, Ohlsson A, Matlow AG (2000) Neonatal escherichia col infections: concerns regarding resistance to current therapy. Acta Paediatr 89: 686-689.

25. Didier C, Streicher MP, Chognot D, Campagni R, Schnebelen A, et al. (2012) Late-onset neonatal infections: incidences and pathogens in the era of antenatal antibiotics. Eur J Pediatr 171: 681-687.

26. Hammoud MS, Al-Taiar A, Thalib L, Al-Sweih N, Pathan S, et al. (2012) Incidence, aetiology and resistance of late-onset neonatal sepsis: a five-year prospective study. J Paediatr Child Health 48: 604-609.

27. Downie L, Armiento R, Subhi R, Kelly J, Clifford V, et al. (2013) Communityacquired neonatal and infant sepsis in developing countries: efficacy of WHO's currently recommended antibiotics--systematic review and meta-analysis. Arch Dis Child 98: 146-154.

28. Terrone DA, Rinehart BK, Einstein MH, Britt LB, Martin JN Jr, et al. (1999) Neonatal sepsis and death caused by resistant Escherichia coli: possible consequences of extended maternal ampicillin administration. Am $\mathrm{J}$ Obstet Gynecol 180: 1345-1348.

29. Coronell W, Perez C, Guerrero C, Bustamante H (2009) Sepsis neonatal. Rev. Enferm. Infec. Pedr. 23: 57-68.

30. Ng PC, Lam HS (2010) Biomarkers for late-onset neonatal sepsis: cytokines and beyond. Clin Perinatol 37: 599-610.

31. Ng PC (2004) Diagnostic markers of infection in neonates. Arch Dis Child Fetal Neonatal Ed 89: F229-235.

32. Muller-Pebody B, Johnson AP, Heath PT, Gilbert RE, Henderson KL, et al (2011) Empirical treatment of neonatal sepsis: are the current guidelines adequate? Arch Dis Child Fetal Neonatal Ed 96: F4-8.

33. Guiral E, Bosch J, Vila J, Soto SM (2012)Antimicrobial resistance of Escherichia coli strains causing neonatal sepsis between 1998 and 2008. Chemotherapy 58: $123-128$

34. Maayan-Metzger A, Barzilai A, Keller N, Kuint J (2009) Are the "good old" antibiotics still appropriate for early-onset neonatal sepsis? A 10 year survey. Isr Med Assoc J 11: 138-142.

35. Thaver D, Ali SA, Zaidi AK (2009) Antimicrobial resistance among neonatal pathogens in developing countries. Pediatr Infect Dis J 28: S19-21.

36. Ramos JM, Milla A, López-García P, Gutiérrez F (2009) [Colonization by Streptococcus agalactiae in foreign and Spanish gestating women in the area of Elche (Spain)]. Enferm Infecc Microbiol Clin 27: 249-251.

37. Javanmanesh F, Eshraghi N (2013) Prevalence of positive recto-vaginal culture for Group B streptococcus in pregnant women at 35-37 weeks of gestation. Med J Islam Repub Iran 27: 7-11.

38. Hamedi A, Akhlaghi F, Seyedi SJ, Kharazmi A (2012) Evaluation of group B Streptococci colonization rate in pregnant women and their newborn. Acta Med Iran 50: 805-808.

39. Brzychczy-Wloch M, Wojkowska-Mach J, Helwich E, Heczko PB (2013) Incidence of maternal GBS colonization and neonatal GBS disease among very low birth weight Polish neonates. Med Sci Monit 19: 34-39.

40. Yu HW, Lin HC, Yang PH, Hsu CH, Hsieh WS, et al. (2011) Group B streptococcal infection in Taiwan: maternal colonization and neonatal infection. Pediatr Neonatol 52: 190-195.

41. Verani JR, McGee L, Schrag SJ; Division of Bacterial Diseases, National Center for Immunization and Respiratory Diseases, Centers for Disease Contro and Prevention (CDC) (2010) Prevention of perinatal group B streptococcal disease--revised guidelines from CDC, 2010. MMWR Recomm Rep 59: 1-36.

42. Andreu A, Sanfeliu I, Viñas L, Barranco M, Bosch J, et al. (2003) [Decreasing incidence of perinatal group B streptococcal disease (Barcelona 1994-2002). Relation with hospital prevention policies]. Enferm Infecc Microbiol Clin 21: 174-179.

43. Lopez Sastre JB, Fernandez Colomer B, Coto Cotallo GD, Ramos Aparicio A Grupo de Hospitales Castrillo (2005) Trends in the epidemiology of neonatal sepsis of vertical transmission in the era of group B streptococcal prevention. Acta Paediatr. 94: 451-457.

44. Centers for Disease Control and Prevention (CDC) (2005) Disparities in universal prenatal screening for group B streptococcus--North Carolina, 2002 2003. MMWR Morb Mortal Wkly Rep 54: 700-703.

45. Schrag S, Gorwitz R, Fultz-Butts K, Schuchat A (2002) Prevention of perinatal group B streptococcal disease. Revised guidelines from CDC. MMWR Recomm Rep 51: 1-22.

46. Edwards RK, Jamie WE, Sterner D, Gentry S, Counts K, et al. (2003) Intrapartum antibiotic prophylaxis and early-onset neonatal sepsis patterns. Infect Dis Obstet Gynecol 11: 221-226.

47. Laugel V, Kuhn P, Beladdale J, Donato L, Escande B, et al. (2003) Effects of antenatal antibiotics on the incidence and bacteriological profile of early-onse neonatal sepsis. A retrospective study over five years. Biol Neonate 84: 24-30

48. Kimura K, Suzuki S, Wachino J, Kurokawa H, Yamane K, et al. (2008) First molecular characterization of group $B$ streptococci with reduced penicillin susceptibility. Antimicrob Agents Chemother 52: 2890-2897.

49. Kimura K, Matsubara K, Yamamoto G, Shibayama K, Arakawa Y (2013) Active screening of group B streptococci with reduced penicillin susceptibility and altered serotype distribution isolated from pregnant women in Kobe, Japan. Jpn J Infect Dis 66: 158-160.

50. Nagano N, Nagano Y, Kimura K, Tamai K, Yanagisawa H, et al. (2008) Genetic heterogeneity in pbp genes among clinically isolated group B Streptococci with reduced penicillin susceptibility. Antimicrob. Agents Chemother. 52: 4258-4267.

51. Kimura K, Nagano N, Nagano Y, Suzuki S, Wachino J, et al. (2013) High frequency of fluoroquinolone- and macrolide-resistant streptococci among clinically isolated group B streptococci with reduced penicillin susceptibility. J. Antimicrob. Chemother. 68: 539-542.

52. Capanna F, Emonet SP, Cherkaoui A, Irion O, Schrenzel J, et al. (2013) Antibiotic resistance patterns among group B Streptococcus isolates: implications for antibiotic prophylaxis for early-onset neonatal sepsis. Swiss Med. Wkly. 143: w13778.

53. Gonzalez JJ, Andreu A, Grupo de Estudio de Infección Perinatal, Sociedad Española de Enfermedades Infecciosas y Microbiología Clínica (2004) Susceptibility of vertically transmitted Group B streptococci to antimicrobia agents. Multicenter study. Enferm. Infecc. Microbiol. Clin. 22: 286-291.

54. Towers CV, Carr MH, Padilla G, Asrat T (1998) Potential consequences of widespread antepartal use of ampicillin. Am J Obstet Gynecol 179: 879-883.

55. Lin CY, Hsu CH, Huang FY, Chang JH, Hung HY, et al. (2011) The changing face of early-onset neonatal sepsis after the implementation of a maternal group B Streptococcus screening and intrapartum prophylaxis policy--a study in one medical center. Pediatr. Neonatol. 52: 78-84.

56. Levine EM, Ghai V, Barton JJ, Strom CM (1999) Intrapartum antibiotic prophylaxis increases the incidence of gram-negative neonatal sepsis. Infect Dis Obstet Gynecol 7: 210-213.

57. Daley AJ, Isaacs D, Australasian Study Group for Neonatal Infections (2004) Ten-year study on the effect of intrapartum antibiotic prophylaxis on early onse group B streptococcal and Escherichia coli neonatal sepsis in Australasia. Pediatr. Infect. Dis. J. 23: 630-634. 